\title{
Wpływ geograficznego, społecznego i ekonomicznego środowiska Afryki Wschodniej na omański model osadnictwa w latach 1806-1856
}

\author{
Sebastian Żbik \\ https://orcid.org/0000-0002-9820-6132 \\ Uniwersytet Warszawski
}

Zarys treści: Artykuł jest analizą wpływu odmiennych warunków geograficznych, społecznych i ekonomicznych Afryki Wschodniej na model osadnictwa Omańczyków w latach 1806-1856. Wskazuje, że doszło w nim do istotnych zmian, obejmujących pojawienie się nowych form osadnictwa, nowego materiału budowlanego czy przyjęcie rozwiązań praktykowanych przez kultury afrykańskie. $\mathrm{Z}$ drugiej strony bardzo wiele ważnych elementów, jak architektura i plemienna struktura osadnictwa, przeniesionych zostało na grunt Afryki Wschodniej.

Słowa kluczowe: Oman, Zanzibar, Afryka Wschodnia, osadnictwo, plantacje goździków, architektura, geografia, Suahili, handel, XIX wiek

Osiedlanie się Omańczyków w Afryce Wschodniej w latach 1806-1856 nie było ani pierwszym tego typu zjawiskiem, ani ostatnim ${ }^{1}$. Jego wyjątkowość zasadza się na kilku czynnikach. Po pierwsze, wyróżniało się liczebnością - na przykład w 1804 r. na wyspie Zanzibar, która od 1697 r. znajdowała się pod panowaniem omańskim, miało mieszkać jedynie 300 Arabów²,

\footnotetext{
${ }^{1}$ Pierwsze wzmianki historyczne na temat omańskiego osadnictwa w Afryce Wschodniej datują je na VIII w. Kolejny impuls nastąpił w 1697 r., kiedy tereny na wybrzeżu Afryki Wschodniej dostały się pod kontrolę polityczną Omanu. Sama migracja zakończyła się w 1964 r., wraz z wybuchem rewolucji na Zanzibarze i obaleniem arabskiego sułtanatu, w rezultacie czego większość Omańczyków i osób pochodzenia omańskiego została zmuszona do emigracji. Mimo to do dzisiaj w Afryce Wschodniej żyją osoby wywodzące swój rodowód z Omanu. Zainteresowanie tego państwa Afryką Wschodnią miało różnorakie podłoże. Jednym z najważniejszych czynników, który umożliwił kontakty między oboma regionami w okresie przednowoczesnym, były wiatry monsunowe. Przez jedną część roku umożliwiały one sprawną żeglugę z Arabii do Afryki, a przez drugą - powrót do Omanu.

2 F. Albrand, Extrait d'un memoire sur Zanzibar et sur Quiloa, „Bulletin de la Société de Géographie", 10, 1838, s. 72.
}

Abstract: The present article analyses the impact of different East African geographical, social and economic conditions on the settlement model of the Omani in this area in 1806-1856. The article indicates that the Oman settlement model has undergone significant changes, including the appearance of new forms of settlement, a change in building material, and the adoption of solutions practiced by African cultures. On the other hand, however, many important elements, such as the architecture and tribal settlement structure, were transferred to East Africa.

Keywords: Oman, Zanzibar, East Africa, settlement, clove plantations, architecture, geography, Swahili, trade, $19^{\text {th }}$ century

a ponad pół wieku później - już z górą 5 tys. ${ }^{3}$ Powstanie w krótkim czasie licznej wspólnoty omańskiej w Afryce Wschodniej powodowało, że nie asymilowała się z lokalną kulturą Suahili tak szybko, jak poprzedni osadnicy. Dodatkowo wpłynęła na to decyzja omańskiego władcy Sa ${ }^{‘} \mathrm{ida}^{4}$ Ibn Sulțāna5, który w 1840 r. przeniósł

${ }^{3}$ R.F. Burton, Zanzibar: city, island, and coast, vol. 1, London 1872, s. 368. Powyższe dane są mocno niepewne i maja jedynie charakter szacunkowy. Sam Richard Burton zdaje sobie sprawę z problemu określenia liczby ludności miasta Zanzibar - podaje co prawda 25 tys., ale jednocześnie zaznacza, że w okresie napływu kupców i niewolników mogto to być nawet 45 tys.

${ }^{4}$ Transkrypcji alfabetu arabskiego ISO (UW) oraz pisma stosowanego w innych językach orientalnych (suahili) dokonuję w artykule według zasad przyjętych w polskiej orientalistyce. Poza imionami słowa z języków orientalnych przytaczane bezpośrednio ze źródeł europejskich zostały zachowane w niezmienionej formie. Nie transkrybuję wyrazów, które są przyjęte i powszechnie używane w formie spolszczonej (nazw miejscowości, tytułów etc.).

${ }^{5}$ Władca z dynastii Āl Busa'ĩ̄i panował w latach 1806-1856. Formalnie rządził całym historycznym Omanem, ale faktycznie jego władza była mocno ograniczona przez omańskie plemiona i opozycję wewnątrz 
swoją siedzibę z Maskatu do Zanzibaru, w wyniku czego w Afryce Wschodniej powstał silny ośrodek arabskiej kultury, który przetrwał tam aż do $1964 \mathrm{r}$.

Podjęta przez Sa īda i tysiące Omańczyków decyzja o osiedleniu się w Afryce Wschodniej była konsekwencją przemian, jakie zaszły w Omanie oraz na ziemiach dzisiejszych Kenii i Tanzanii. Sa'ìd, w przeciwieństwie do swoich poprzedników, prowadził w regionie Afryki Wschodniej aktywną politykę, dzięki czemu przywrócił kontrolę nad większością wybrzeża, utraconą po 1749 r., kiedy część zamieszkujących je omańskich plemion skutecznie wypowiedziała posłuszeństwo władcom w metropolii ${ }^{6}$. Ponowna konsolidacja omańskiego panowania w Afryce Wschodniej przyczyniła się do rozkwitu handlu kością słoniową i niewolnikami z interiorem kontynentu oraz stworzenia systemu plantacji goździków. Przed omańskimi osadnikami otworzyły się nowe możliwości gospodarcze, dające im szansę na szybki awans społeczny i ekonomiczny. W tym samym czasie Oman, pomimo wysiłków Sa îda, cierpiał w wyniku wewnętrznych konfliktów i zewnętrznych najazdów?

Choć Omańczycy osiedlali się w regionie o odmiennych warunkach geograficznych i kulturze, to jednak robili to w ramach jednego organizmu politycznego i w pobliżu nowej siedziby władcy miasta Zanzibar ${ }^{8}$. Rodzi się więc pytanie, na ile model ich osadnictwa był kopią rozwiązań stosowanych w Omanie, a na

własnego rodu. Więcej zob. J. Jones, N. Ridout, $A$ history of modern Oman, London 2015.

${ }^{6}$ Omańskie plemiona w Afryce Wschodniej z klanem Al-Mazrưi na czele nie uznały nowego władcy Aḥmada Ibn Sa'Tda - pierwszego z rodu Āl Busa'î̃̄ - który doszedł do władzy po wojnie domowej między przedstawicielami poprzedniej dynastii. Mimo działań podejmowanych przez Aḥmada Ibn Sa'îda utrata Afryki Wschodniej okazała się trwała i do czasów Sa'īda ibn Sultāna Zanzibar pozostawał jedyną istotną posiadłością omańską w tym regionie.

Więcej na ten temat: M.R. Bhacker, Trade and empire in Muscat and Zanzibar. The roots of British Domination, London 2014.

${ }^{8}$ Było to ostatnie osadnictwo prowadzone w warunkach jedności politycznej Omanu i wybrzeża Afryki Wschodniej. Po 1856 r. zostaną ustanowione odrębne twory polityczne - Sułtanat Omanu i Sultanat Zanzibaru. ile uległ modyfikacji w nowym otoczeniu geograficznym i kulturowym oraz w warunkach szybkich przemian gospodarczych i społecznych. Opisanie tej zmiany lub wykazanie jej braku jest celem niniejszego artykułu'. Przez model osadnictwa należy rozumieć nie tylko sposób i formę zajmowania przestrzeni przez daną grupę ludzi, ale także koncepcję tej przestrzeni, jej architekturę i styl $1^{10}$.

Wobec charakteru materiału źródłowego analizie poddane zostanie przede wszystkim omańskie osadnictwo na wyspie Zanzibar, która jako centrum państwa Sa īda była najczęściej opisywana przez arabskich i zagranicznych autorów ${ }^{11}$. Mimo ograniczeń źródłowych wspomniane zostanie też osadnictwo w innych miejscach Afryki Wschodniej, m.in. w interiorze. Odpowiednie ukazanie zmian, jakie zaszty w omańskim modelu osadnictwa w Afryce Wschodniej, wymaga też przedstawienia modelu funkcjonującego w Omanie.

\section{Oman i jego model osadnictwa}

W okresie przednowoczesnym omański model osadnictwa był ściśle powiązany z klimatem i geografią kraju. Historyczny

\footnotetext{
${ }^{9}$ Aspekty dotyczące zmian, które zaszły w omańskiej wspólnocie Afryki Wschodniej w zakresie kultury, życia codziennego, religii i języka opisane zostały przez autora tego artykułu w pracy pt. Wybrane przykłady zmiany kulturowej wśród omańskiej społeczności w Afryce Wschodniej w latach 1806-1856, która ukaże się w monografii po V Kongresie Afrykanistów Polskich.

${ }^{10} \mathrm{~W}$ związku z ograniczeniem wydawniczym pominięte zostaną tu aspekty wpływu omańskiego osadnictwa na kulturę Suahili oraz środowisko Afryki Wschodniej.

${ }^{11}$ Niewiele arabskich źródeł opisuje omańskie osadnictwo z lat 18061856. Do nielicznych prac z tego tematu należy Ğuhaynat al-ahbār fĩ tārīh Zaniğbār ('Pewność wiadomości o historii Zanzibaru') autorstwa Sa'īda ibn 'Alego Al-Muḡayrīego. Choć jest to dzieło dużo późniejsze niż omawiany okres, zbiera źródła (tradycję ustną, dokumenty prywatne i oficjalne) i tworzy historię omańskiej obecności w Afryce Wschodniej. Drugim istotnym materiałem są wspomnienia córki Sa'īida Ibn Sultāna, Salmy, która wyszła za niemieckiego kupca i przyjęła imię Emily Ruete. Jej dzieło Memoirs of an Arabian princess. An autobiography ukazuje życie wewnętrzne sułtańskiego dworu na Zanzibarze. Ponadto wykorzystano prace europejskich i amerykańskich podróżników, którzy odwiedzali zarówno Maskat, jak i Zanzibar. Do najbardziej cennych relacji należą dzieła angielskiego podróżnika i znawcy Wschodu Richarda Francisa Burtona: The lake regions of Central Africa. A picture of exploration in Zanzibar: city, island, and coast. Artykut bazuje również na opublikowanych wynikach badań archeologicznych oraz dotychczasowej literaturze przedmiotu.
} 


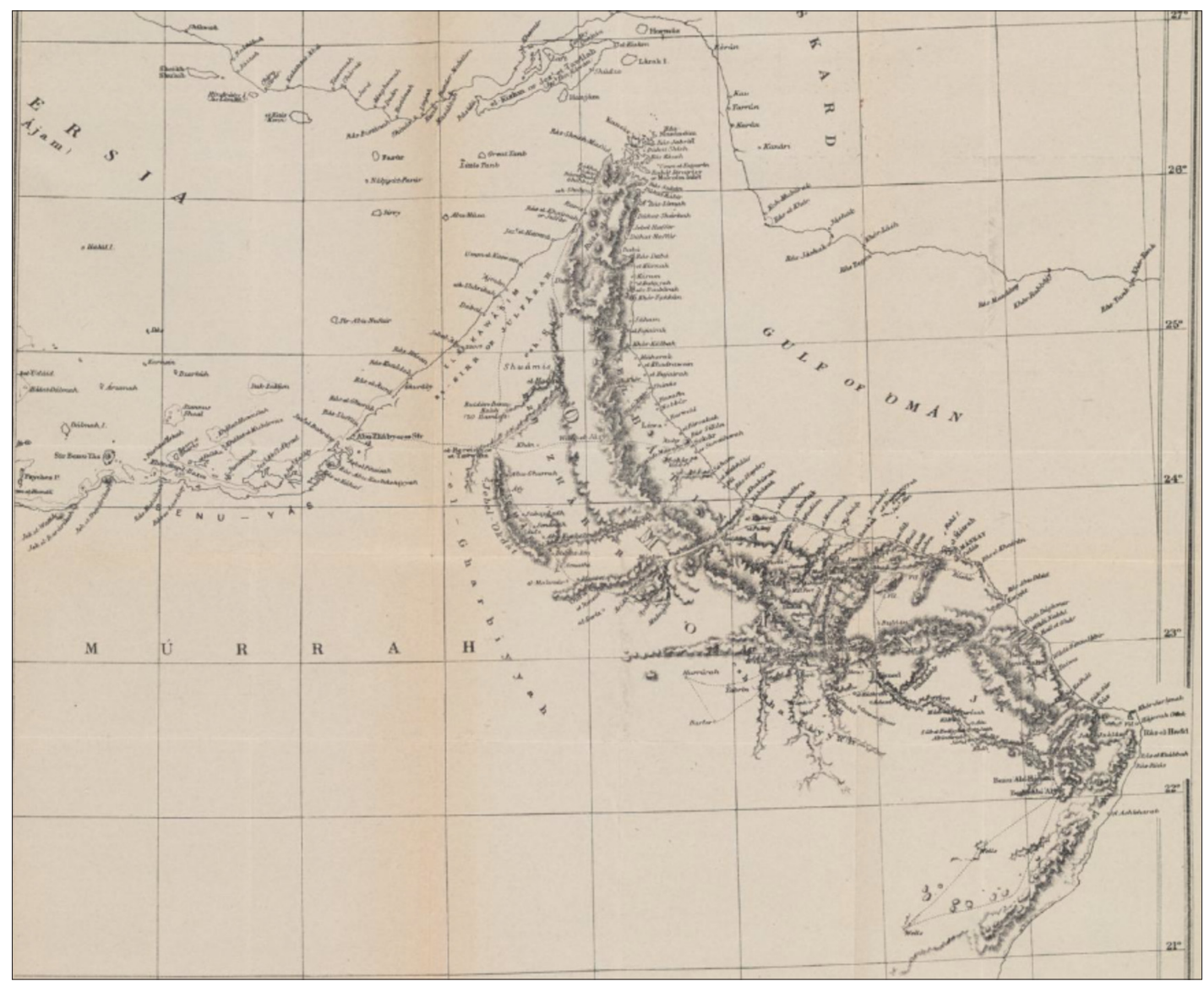

Ryc. 1. Geografia Omanu.

Źródło: F. Kajari, „Le Sultanat d'Oman. La question de Mascate”, Paris 1914

Oman ${ }^{12}$ dzieli się zazwyczaj na trzy regiony: wybrzeże (Al-Bațina), sferę gór, oraz obszar pustynny. Wybrzeże stanowi rozległą równinę ciągnącą się u podnóża masywu górskiego. Tereny położone bliżej brzegu morskiego mają dostęp do wód gruntowych, a do dalszych dostarcza się ją systemem kanałów ${ }^{13}$. Teren górzysty, który nosi nazwę Al-Hadżar (Góry Kamienia), bierze swój początek na półwyspie $\mathrm{Mu}-$ sandam i ciągnie się w głąb Omanu aż do

\footnotetext{
${ }^{12}$ Ziemie historycznego Omanu obejmowały tereny dzisiejszych Zjednoczonych Emiratów Arabskich (emiraty Ras Al-Chajma i Al-Fudżajra dawny Ğulfār) i północną część współczesnego Sułtanatu Omanu. Wchodząca dziś w skład tego państwa południowa prowincja Az-Zưfār została do niego przyłączona w 1829 r., ale integralną częścią kraju stała się dopiero w XX w.

${ }^{13}$ J.C. Wilkinson, The imamate tradition of Oman, Cambridge 1997, s. 21.
}

jego wschodnich granic w pobliżu miasta Sur. Za masywem Al-Hadżar rozciąga się płaskowyż stanowiący interior Omanu.

Klimat Omanu jest pustynny, ciepły, z temperaturami dochodzącymi w lecie do 50 stopni Celsjusza. Opady deszczu są tam bardzo rzadkie i krótkotrwałe, za wyjątkiem obszarów górskich, gdzie w okresie zimowym ich ilość i częstotliwość jest większa ${ }^{14}$. W takich warunkach omańskie osady mogły czerpać wodę z dwóch źródeł - studni głębinowych i systemu poziomych kamiennych kanałów (falăg, l. mn. alfa ğ) poprowadzonych ze stoków górskich

\footnotetext{
${ }^{14}$ Tenże, Water and tribal settlement in South-east Arabia. Study of the aflaj of Oman, Oxford 2013, s. 40.
} 
w kierunku wybrzeża i interioru ${ }^{15}$. Zlokalizowane w górach studnie służyły zarówno do gromadzenia opadów deszczu, jak i pozyskiwania wód gruntowych. By utrzymać wysoki poziom wody i chronić ją przed nadmiernym parowaniem, większą część kanału umieszczano pod powierzchnią ziemi. Poboru wody dokonywano ze studni znajdujących się u podnóża masywów górskich lub z otwartych kanałów, które doprowadzały ją bezpośrednio do domostw i pól uprawnych ${ }^{16}$.

Taka organizacja systemu irygacji miała bezpośrednie implikacje w modelu osadnictwa. Osady korzystające z kanałów były niewielkie i izolowane od siebie. Koncentrowały się wokół studni lub otwartego ujścia kanału, gdzie najbliżej dostępu do wody znajdowały się łaźnie i meczet, a w dalszej kolejności domostwa i budynki gospodarcze. Otaczające osadę pola uprawne zasilano wodą poprzez sieć mniejszych kanałów, a zasady jej poboru były ściśle regulowane przez lokalną wspólnotę. Każdy właściciel ogrodu lub pola uprawnego miał określony czas, kiedy mógł korzystać $\mathrm{z}$ wody $\mathrm{z}$ fala $\breve{g} u^{17}$. W rolnictwie dominowały uprawa palmy daktylowej i hodowla zwierząt. Taki przykład osadnictwa występował głównie w interiorze kraju, a liczba ludności osad przy falağach najczęściej wahała się między 0,5 a 2,5 tys. (osady między 2,5 a 10 tys. należały tam do rzadkości) ${ }^{18}$.

Inną strukturę miało osadnictwo na wybrzeżu, gdzie głównym źródłem wody były studnie głębinowe, a potrzeby żywieniowe ludności zaspokajało także rybołówstwo. Tamtejsze osady występowały w rezultacie

\footnotetext{
${ }^{15}$ Początki systemu irygacyjnego w Omanie nie są do końca jasne. Przyjmuje się, że za stworzenie pierwszych kanałów odpowiadają Persowie, którzy kontrolowali ten obszar w VI w. p.n.e., a sama idea systemu podziemnych kanałów została wynaleziona w państwie Achemenidów. Więcej zob. J.C. Wilkinson, The imamate tradition, s. 88.

${ }^{16}$ Tenże, Water and tribal settlement, s. 74.

${ }^{17}$ A. Al-Ghafiri, H. Nash, M. Al-Sarmi, Timing water shares in Wādī Banī Kharūș, Sultanate of Oman, w: Proceedings of the Seminar for Arabian Studies, vol. 43, ed. L. Weeks, J. Watson, London 2013, s. 1-10.

${ }^{18} \mathrm{~J}$.C. Wilkinson, Water and tribal settlement, s. 17.
}

bliżej siebie, co sprzyjało łączeniu się w większe organizmy. Miejscowości zlokalizowane na wybrzeżu uczestniczyły ponadto $\mathrm{w}$ wymianie handlowej z portami w Zatoce Perskiej, a największe z nich, jak Maskat czy Sur, utrzymywały kontakty z Indiami i Afryką Wschodnią. Prowadzito to do gęstszego zaludnienia wybrzeża i powstawania tam większych ośrodków miejskich, zamieszkiwanych przez ludność zróżnicowaną społecznie i etnicznie. Niemniej jednak tradycyjne omańskie osadnictwo charakteryzowało się brakiem rozbudowanych ośrodków miejskich, najważniejsze porty w okresie swojej świetności nie przekraczały bowiem 50 tys. mieszkańców ${ }^{19}$.

Drugim istotnym czynnikiem kształtującym model osadnictwa w Omanie była struktura społeczna. Do połowy XX w. społeczeństwo tego kraju miało charakter plemienny. Plemiona w pełni osiadłe zajmowały określony obszar (dār), w którym wypasano stada, uprawiano rolnictwo i przemieszczano się. Podstawą organizacji plemiennej był klan ('amāra), który składał się z rodzin $(f a s ̦ i l a)$. Kilka klanów tworzyło plemię (qabila), te zaś grupowały się w sojusze bądź konfederacje (šaff), które zawierano w celu obrony terytorium i zasobów poszczególnych plemion ${ }^{20}$. Do najtrwalszych konfederacji w dziejach Omanu należały sojusze Al-Ḡāfirii i Al-Hināwī, których powstanie wiąże się $\mathrm{z}$ wojną domową toczoną $\mathrm{w}$ latach 1719-1749 między władcami z dynastii Al-Ya rubi $^{-21}$. Podział omańskiego społeczeństwa na te dwie konfederacje nadawał ton polityce Omanu aż do połowy XX w.,

\footnotetext{
19 Tamże, s. 17.

${ }^{20}$ Tamże, s. 93.

${ }^{21}$ John C. Wilkinson dopatruje się początków tej dychotomii na długo przed wojną domową. Wskazuje, że konflikt między głównymi plemionami obu konfederacji miał długą historię i wpisywał się w liczne waśnie międzyplemienne, których głównym motorem była walka 0 dostęp do źródeł wody i pastwisk. Na dużo wyższy poziom plemienną waśń wyniosły dopiero warunki wojny domowej oraz polityka antagonizowania plemion dla celów politycznych uprawiana przez kolejnych pretendentów do tronu. Więcej zob. J.C. Wilkinson, The imamate tradition, s. 223.
} 
odgrywając również istotną rolę w osadnictwie w Afryce Wschodniej.

Podziały plemienne bezpośrednio wpływały na model osadnictwa. Najlepiej ilustruje to miejscowość Izki w interiorze Omanu, w pobliżu której leżały dwie osady - Nizār i Yaman - zamieszkiwane przez dwie zwaśnione grupy plemion wywodzące się z tradycyjnego podziału plemion arabskich na północne i południowe ${ }^{22}$. Podziały tego rodzaju odgrywały też ważną rolę na poziomie samych miejscowości. Jeśli w osadzie mieszkało wiele plemion, to domostwa należące do członków każdego z nich znajdowały się obok siebie, a w większych miejscowościach poszczególne plemiona lub klany miały swoją własną dzielnicę (hara). Na poziomie dāru wrogie konfederacje sąsiadowały natomiast ze soba, a co za tym idzie istniał pretekst do ciągłych waśni i groźba wojny. Omańskie osady musiały być więc wyposażone w systemy obronne, najczęściej składające się z muru i wież. Przy większych miejscowościach lub w miejscach strategicznych budowano forty i twierdze. W zamkach (hișn) lub fortach ( qi la) rezydowali również omańscy władcy, noszący do końca XVIII w. tytuł imamów.

Osady w interiorze Omanu zamieszkiwali członkowie plemion, ludność zależna oraz niewolnicy, natomiast w miastach portowych, a szczególnie w Maskacie, kompozycja społeczna była o wiele bardziej zróżnicowana. Obok Omańczyków mieszkali tu także hinduscy kupcy. Pierwsze ślady ich obecności datuje się na XV w. ${ }^{23}$, a w większej liczbie zaczęli się osiedlać w Maskacie za czasów portugalskich ${ }^{24}$, służąc za pośredników w handlu z Indiami. Zajmowali się tym także po odbiciu miasta przez Omańczyków, aż do końca

\footnotetext{
22 Documentation and heritage management plan of Hārat al-Yemen Muscat 2013, s. 22

${ }^{23}$ S.B. Miles, The countries and tribes of the Persian Gulf, vol. 2, London 1919, s. 250

${ }^{24}$ W latach 1507-1651 wybrzeże 0manu znajdowało się pod kontrolą portugalską
}

XIX w. ${ }^{25} \mathrm{~W}$ omańskich miastach osiedlali się również kupcy z różnych regionów $\mathrm{Za-}$ toki Perskiej oraz Beludżowie ${ }^{26}$. Ci ostatni stanowili sporą społeczność, służyli bowiem władcom Maskatu jako najemni żołnierze i oficerowie. Wszystkie te grupy etniczne i religijne zamieszkiwały osobne dzielnice, nierzadko oddzielone od siebie murami i bramami ${ }^{27}$.

Omańskie miasta i wioski miały nieregularny kształt. Charakteryzowały się zwartą zabudową oraz gęstą siatką krętych ulic. Ich centralnymi punktami były zazwyczaj targi $(s \bar{u} q)$ i meczety. W miastach portowych najważniejsze budynki umieszczano przy nadbrzeżu, stąd też w Maskacie zarówno pałac władcy i forty, jak również urząd celny oraz budynki administracyjne znajdowały się nad brzegiem morza ${ }^{28}$. Budynki w miastach i osadach stały blisko siebie, a w obrębie murów poza domostwami, meczetami i targiem znajdowały się jeszcze łaźnie (osobne dla kobiet i mężczyzn), miejsce spotkań mężczyzn (burrad lub sabla), magazyny, budynki gospodarcze oraz zagrody dla zwierząt i stajnie. Jak już wspomniano, osady otoczone były przez należące do mieszkańców pola uprawne i gaje palmowe ${ }^{29}$.

Omańska architektura reprezentowała wzorce arabskie. Budynki były proste,

\footnotetext{
${ }^{25}$ Jedynymi z pierwszych osadników w Maskacie byli Sindhowie z klanu Bhatțiyā. W późniejszym okresie ich rolę w większości przejęli hinduscy kupcy z Kaćch (Gudżarat), którzy w XIX w. jako poborcy cet i źródło kredytów nabrali ogromnego znaczenia w omańskiej gospodarce. Trzecią istotną grupą kupców z Indii byli Chodżowie, w Omanie znani jako Luwāttiyya. Ich rodowód nie jest jasny; wywodzili się zapewne z Hajdarabadu, a niektóre źródła wskazują na pochodzenie z innego klanu Bhatțiyā, który przeszedł na islam w wersji ismailickiej. Więcej zob. C.H. Allen, The Indian merchant community in Masqat, „Bulletin of SOAS", 44 (1), 1981.

${ }^{26}$ Beludżowie to grupa etniczna zamieszkująca dzisiejsze pogranicza Iranu i Pakistanu - Beludżystan. 0 roli tego regionu w kontaktach z Omanem i Zanzibarem zob. B. Nicolini, Makran, Oman and Zanzibar. Three-terminal cultural corridor in the western Indian Ocean (1799-1856), Leiden 2004.

${ }^{27}$ E. Roberts, Embassy to the eastern courts of Cochin-China, Siam, and Muscat, New York 1837, s. 358.

${ }^{28}$ W.S. Ruschenberger, Narrative of a voyage round the world, vol. 1 , London 1838, s. 108.

${ }^{29} \mathrm{Ibri}$, ārat As-Sulayf. Documentation and heritage management plan, Muscat 2013, s. 19
} 


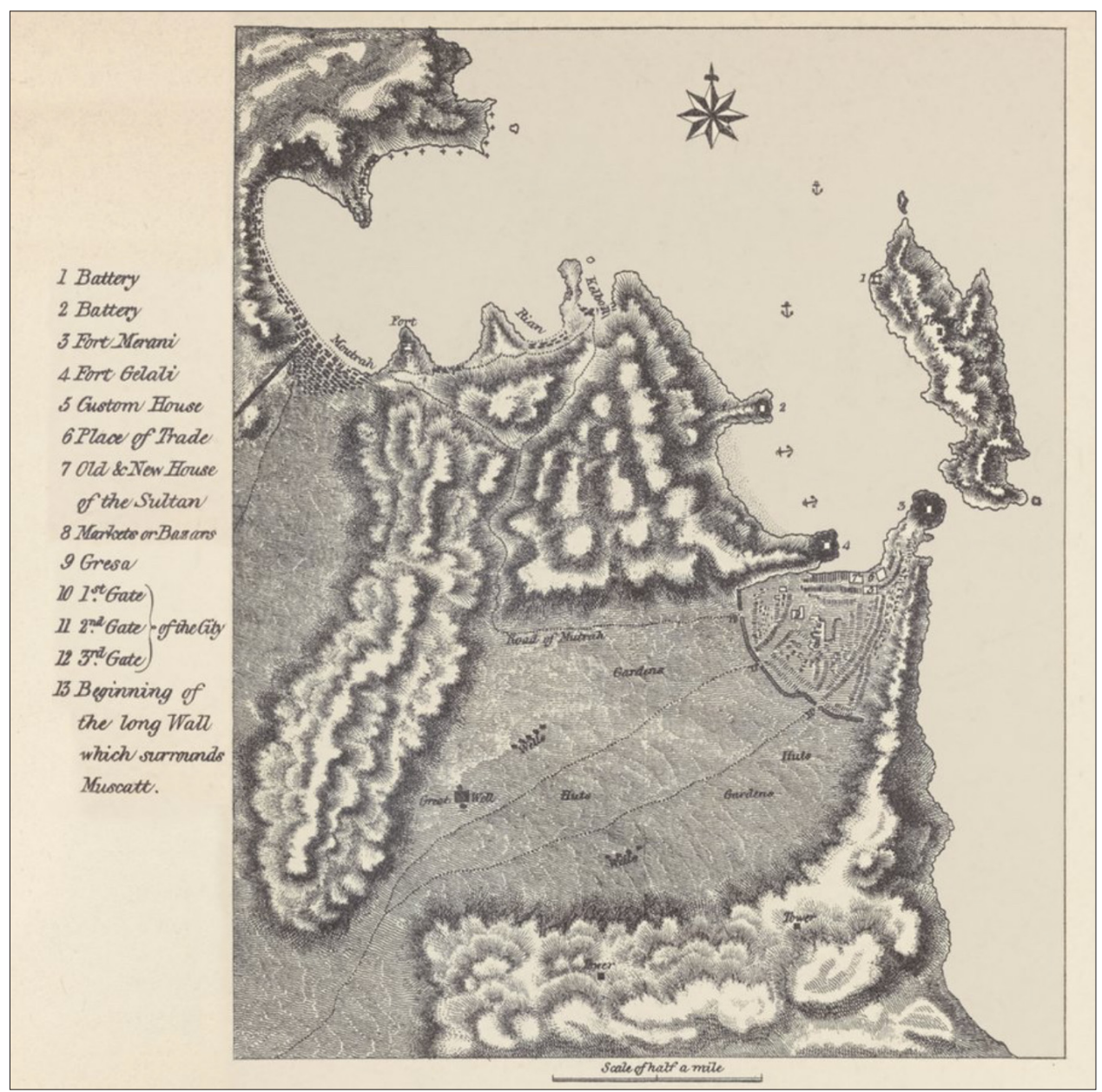

Ryc. 2. Plan Maskatu w pierwszej połowie XIX w.

Żródto: V. Maurizi, „History of Seyd Said, Sultan of Muscat”, London 1819

z płaskimi dachami oraz małymi oknami. Zdecydowaną większość z nich wykonano z suszonej cegły i tylko niektóre konstrukcje, takie jak wieże czy najważniejsze twierdze, powstawały z kamienia. Do konstruowania dachu wykorzystywano palmę daktylową: pnie służyły jako belki, na których układano ściśle splecione i wysuszone liście. Charakterystyczną cechą omańskich domostw były nisze, w których trzymano przedmioty codziennego użytku. Pozostałe rzeczy, w tym ubrania i kosztowności, przechowywane były w skrzyniach, które stanowiły jedne z nielicznych mebli omańskiego domu. Nie korzystano z krzeseł ani stołów, jadano bowiem na ziemi, używając do tego jedynie rąk ${ }^{30}$. Ludność zależna i niewolnicy mieszkali na obrzeżach osad lub na przedmieściach miast

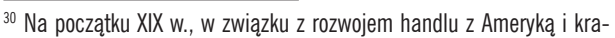
jami europejskimi, napływały do Omanu zachodnie sprzęty i meble. Europejscy i amerykańscy podróżnicy potwierdzają obecność krzeseł i stołów, a także takich dekoracji, jak zegary czy lustra. Z Indii i innych krajów Wschodu przywożono z kolei porcelanę i niektóre meble. Warto jednak pamiętać, że innowacje te występowały jedynie w pałacu władcy i domach wysokich dostojników. Nawet tam jednak zakres zmian mógł być ograniczony, tak jak w przypadku spożywania posiłku przy stole, które odbywało się w pałacu Sa'îda tylko przy okazji odwiedzin delegacji zagranicznych.
} 
portowych, w chatach zrobionych z mat i trzciny ${ }^{31}$.

Prostotą i regularnymi kształtami cechowały się również meczety ibadyckie ${ }^{32}$. W Omanie nie budowano minaretów, a mihrab (wnęka wskazująca kierunek Mekki), w przeciwieństwie do podobnych konstrukcji w wielu krajach muzułmańskich, pozbawiony był dekoracji ${ }^{33}$. Również nagrobki stawiano w Omanie proste - była to skromna stela $\mathrm{z}$ wyrytym imieniem i fragmentem Koranu ${ }^{34}$. Tak samo wyglądały miejsca pochówku władców, z tą różnica, że nie grzebano ich na wspólnych cmentarzach, ale na terenie własnej posiadłości lub w jej pobliżu.

\section{Środowisko geograficzne i społeczne Afryki Wschodniej}

Mimo wieków wspólnych relacji przez Ocean Indyjski Omańczycy, którzy osiedlali się w Afryce Wschodniej ${ }^{35}$ w latach 1806-1856, musieli się mierzyć z odmiennym klimatem i kulturą. Jest to obszar o klimacie monsunowym, charakteryzujący się wysokimi temperaturami i dużą wilgotnością powietrza. Od kwietnia do września trwa tam pora deszczowa, powodowana przez południowowschodni monsun zwany kusi ${ }^{36}$. Wybrzeże ma natomiast charakter odrębnej niszy ekologicznej: występują na nim większe niż w pozostałych

\footnotetext{
${ }^{31}$ W.S. Ruschenberger, Narrative, s. 118.

${ }^{32}$ Ibadyzm był dominującym w Omanie odłamem islamu. Więcej zob. J. Hoffman, The essentials of Ibadi Islam, Syracuse 2012.

${ }^{33}$ P.M. Costa, Historic mosques and shrines of Oman, London 2001, s. 14

${ }^{34}$ M.M. Ibrahim, Tombs and their inscriptions from Nizwā and al-Haymali, Sultanate of Oman, w: Proceedings of the Seminar for Arabian Studies, vol. 31, Oxford 2001, s. 100.

${ }^{35}$ Pojęcie Afryki Wschodniej jest bardzo umowne i w zależności od klasyfikacji obejmuje różne kraje. W najszerszej wersji dotyczy państw od Erytrei na północy po Mozambik na południu, w najwężzzej zaś - kraje Wspólnoty Wschodnioafrykańskiej (EAC): Burundi, Kenię, Rwandę, Tanzanię i Ugandę. W XIX w. i wcześniej w ramach obszaru Afryki Wschodniej wyróżnia się wybrzeże, gdzie funkcjonowała cywilizacja Suahili, oraz interior, zamieszkały przez niemuzułmańskie ludy afrykańskie. Zazwyczaj przyjmuje się, że cywilizacja Suahili zajmowała obszar od ujścia rzeki Juba aż po przylądek Delgado na południu. Więcej zob. M.N. Pearson, Port cities and intruders. The Swahili Coast, India and Portugal in the early modern era, Baltimore 1998, s. 19

${ }^{36}$ R.L. Pouwels, Horn and crescent. Cultural change and traditional Islam on the East African coast, Cambridge 2002, s. 8.
}

obszarach Afryki Wschodniej opady deszczu, a szczególnie w północnej części klimat jest dużo bardziej zróżnicowany i nieprzewidywalny ${ }^{37}$.

Afrykę Wschodnią zamieszkiwali przede wszystkim Suahili i plemiona niemuzułmańskie ${ }^{38}$. Wśród tych ostatnich można wyróżnić ludy Mijikenda, Zaramo i Zigua na południu oraz Somalijczyków i Oromo na północy wybrzeża ${ }^{39}$. Suahili to z kolei ludność muzułmańska pochodzenia afrykańsko-azjatyckiego, mówiąca językiem suahili. W odniesieniu do omawianego okresu nie możemy jednak mówić o jednej kulturze Suahili, a raczej o lokalnych kulturach posługujących się dialektami tego języka i połączonych wyznawaniem islamu sunnickiego ${ }^{40}$. Istotną cechą suahilijskiego społeczeństwa był jego miejski charakter ${ }^{41}$.

Suahilijskie osadnictwo zazwyczaj dzieli się na dwa typy - miasta (tzw. kamienne miasta) i osady. Pierwsze były ważnymi centrami politycznymi i handlowymi, które poza lokalną społecznością zamieszkiwali zagraniczni kupcy i przybysze $z$ interioru. Miasta lokowano na przybrzeżnych wyspach oraz na samym wybrzeżu; ważny był dostęp do wody pitnej i możliwość transportu korala, który służył za główny materiał do budowy suahilijskich miast $^{42}$. Miasta stanowiły również miejsce

\footnotetext{
${ }^{37}$ Tamże.

${ }^{38}$ U progu XIX w. wybrzeże Afryki Wschodniej zamieszkiwała też ludność hinduska, szczególnie grupy z regionu dzisiejszego Gudżaratu, a także Bombaju. Poza tym żyli tam Arabowie z Jemenu i Omanu (starsza migracja sprzed 1806 r., mocno zasymilowana z ludnością Suahili). ${ }^{39}$ Mijikenda zamieszkiwali pierwotnie okolice Mombasy i Malindi, będąc pośrednikami handlowymi między wybrzeżem a interiorem Afryki. Co więcej, współpracowali z Suahili w zakresie obrony, a niektórzy wchodzili w stosunki klientelistyczne z bogatymi rodami wybrzeża. Posługiwali się podobnym do suahili językiem z grupy bantu, a mimo to traktowano ich w miastach jako cudzoziemców, wobec czego małżeństwa pomiędzy nimi a Suahili były wykluczone. Posługujący się językiem z rodziny kuszyckiej Oromo zamieszkiwali natomiast pótnoc dzisiejszej Kenii oraz obszary Etiopii i Somalii. Prowadzili półnomadyczny tryb życia, wędrując z bydłem przez deszczową porę roku, w suchej zaś zatrzymywali się w rejonie ujścia Tany. W niewielkiej liczbie zamieszkiwali też archipelag Lamu.

${ }^{40}$ C.S. Nicholls, The Swahili Coast. Politics, diplomacy and trade on the East African littoral, 1798-1856, London 1971, s. 24.

${ }^{41}$ R.L. Pouwels, Horn, s. 33

${ }^{42}$ M.N. Pearson, Port cities, s. 75.
} 


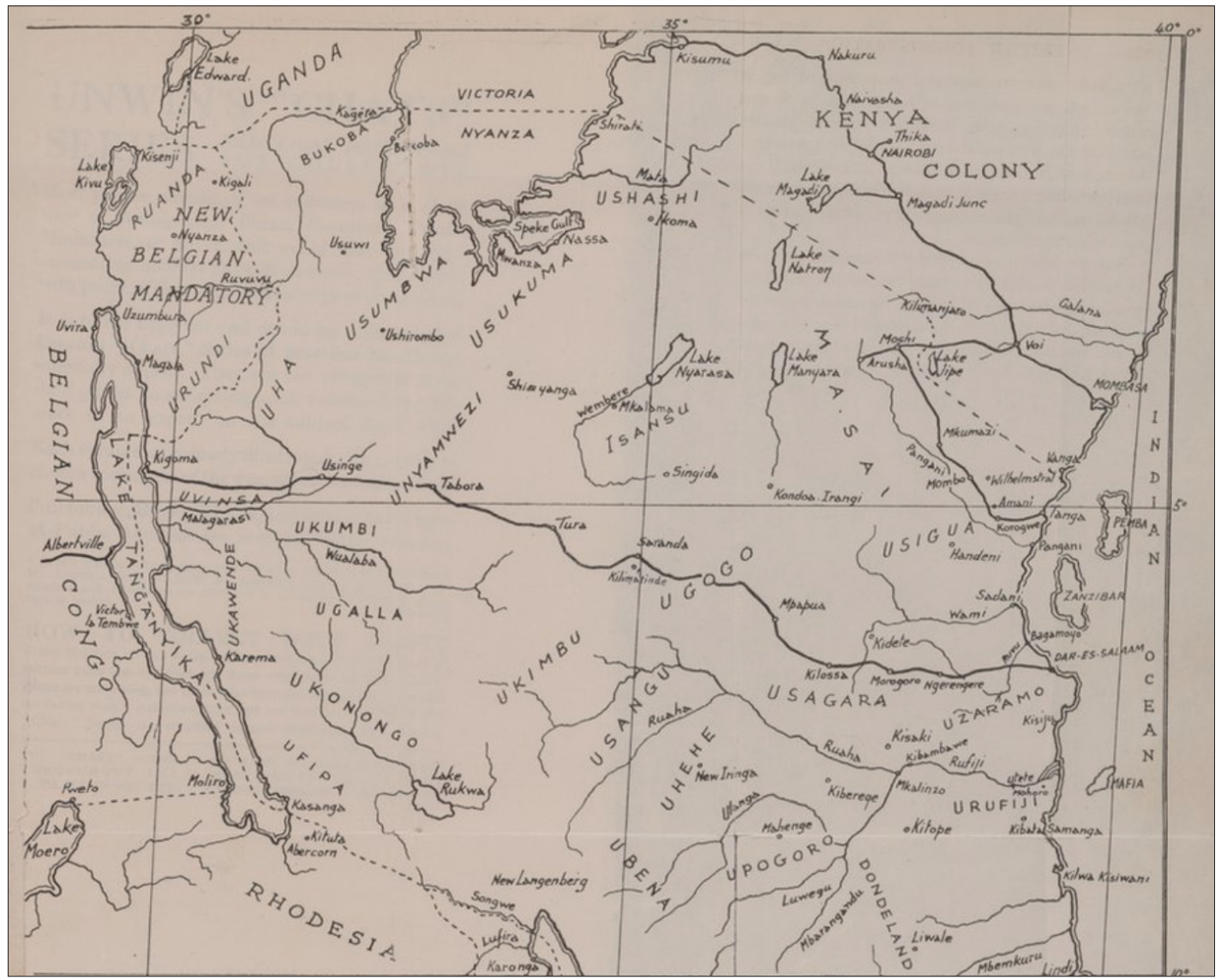

Ryc. 3. Wyspy Zanzibar i Pemba oraz interior Afryki Wschodniej.

Żródto: F.S. Joelson, „The Tanganyika territory (formerly German East Africa). Characteristics and potentialities”, London 1920, s. 291

rezydowania władz politycznych, czyli sułtana i jego gubernatorów $w^{43}$. Wsie Suahili zamieszkiwali z kolei głównie rybacy i rolnicy, stąd ich organizacja i gospodarka kierunkowane były na produkcję żywności. Mieszkańcy żyli w pojedynczych domach (nyumba). Część pracowała na plantacjach należących do elity, inni posiadali własne, a pozostali zatrudniali się jako służący czy żeglarze ${ }^{44}$.

Układ zabudowy mieszkalnej różnił się od tej, którą można było spotkać

\footnotetext{
${ }^{43}$ Brak jednej kultury Suahili wiąże się również z brakiem jedności politycznej wybrzeża. W przeciwieństwie do Omanu każde miasto czy osada w Afryce Wschodniej miało oddzielną, choć podobną strukturę polityczną. Na ich czele stali władcy, zazwyczaj noszący tytuł sułtana. Ich władza ograniczała się jednak jedynie do miasta i okolicznych osad. ${ }^{44}$ R.L. Pouwels, Horn, s. 77.
}

w Omanie. W suahilijskich domach życie prywatne koncertowało się w głębszej części budynku, natomiast pomieszczenia najbliższe wejściu służyły do przyjmowania gości, w związku z czym odnośnie do suahilijskiego domu sformułowano koncepcję gradacji prywatności $i^{45}$. W obu kulturach występowały jednak charakterystyczne ściany z niszami, gdzie trzymano przedmioty (suah. zidaka), oraz pomieszczenia do przyjmowania gości (suah. madaka, arab. baraza). Podobne były także fasady - w obu przypadkach proste, z niewielkimi oknami. Wnętrze suahilijskiego domu było jednak bogato

${ }^{45}$ L. Donley, House power. Swahili space and symbolic markers, w: Sym-
bolic and structural archeology, ed. I. Hodder, Cambridge 1982, s. 67. 
zdobione, a elementy dekoracji stanowiły zidaka, ozdobne panele czy sztukateria wykonana z tynku lub drewna namorzynowego ${ }^{46}$. W związku z handlowym i miejskim charakterem cywilizacji Suahili część domów łączyła w sobie funkcje mieszkalne i handlowe, mieszcząc na parterze sklepy i magazyny ${ }^{47}$.

\section{Omańskie osadnictwo w miastach i osadach na wybrzeżu Afryki Wschodniej}

Omańczycy, którzy po 1806 r. zdecydowali się przybyć do Afryki Wschodniej, osiedlali się głównie na wyspie Zanzibar. Już przed 1806 r. na miejscu, w którym powstało później miasto o tej samej nazwie, istniała suahilijska osada, zamieszkana także przez potomków Arabów z Omanu przybyłych we wcześniejszych migracjach. Co więcej, na wyspie rezydował też namiestnik z Maskatu. Działalność polityczna i ekonomiczna Sa'īda Ibn Sulțāna zmieniła jej obraz, przekształcając osadę w dynamicznie rozwijające się miasto, a okoliczne tereny pokryły się plantacjami goździków należącymi do omańskiej elity.

Miasto Zanzibar, zamieszkane przez ludność rozmaitego pochodzenia, podzielone zostało na dzielnice (arab. harät, suah. mitaa). Omańskie osadnictwo dokonywało się tam w oparciu o przynależność plemienną, czyli powielało tradycje istniejące w Omanie. Na przykład klan Al-Barwanī zamieszkał głównie w dzielnicy Baghani, która znajdowała się w centrum miasta. Dawną dzielnicę portugalską zajmował klan Al-Mahrumī, a jeszcze inny, Al-Mahrūbī, zamieszkał w Shangani - dzielnicy znajdującej się na zachód od Baghani (na cyplu). Poniżej Baghani i na wschód od Shangani znajdowała się dzielnica Mbaraka arabu, zamieszkała przez Al-Mandirīch, reprezentujących konfederację Al-Ḡāfirī. Kolejne przynależące do niej klany, Ar-Riyāmi i Al-Maskarī, mieszkały w pobliżu

\footnotetext{
${ }^{46} \mathrm{~A}$. Sheriff, Zanzibar stone town. An architectural exploration, Zanzibar 1998, s. 16.

${ }^{47}$ Tamże, s. 15.
}

Kajificheni. W północno-wschodniej części miasta, w dzielnicy Malindi, rezydowali natomiast przedstawiciele rodu panującego w Omanie - Āl Busa 'īdī ${ }^{48}$. Oczywiście poza wspomnianymi grupami w wymienionych dzielnicach mieszkali Omańczycy $\mathrm{z}$ innych plemion.

Osadnictwo plemion poszczególnych konfederacji miało o wiele bardziej zwarty charakter niż w Omanie, gdzie rodziny należące do konfederacji Al-Ḡāfirī i Al-Hināwī zamieszkiwały obok siebie. W Zanzibarze pierwsza $\mathrm{z}$ tych konfederacji zajmowała trzy sąsiadujące ze sobą dzielnice i choć otoczona była przez dystrykty zdominowane przez tę drugą, to generalnie żyła w skupieniu. Taki stan rzeczy możliwy był dzięki tworzeniu struktury osadniczej praktycznie od podstaw. Plemiona dobierały miejsce zamieszkania wedle przynależności do konfederacji, co cementowało podziały, ale jednocześnie ograniczało pole do konfliktów.

Co więcej, na Zanzibarze podział na dzielnice nie był zamknięty jak w Omanie - obok Arabów mieszkali w nich także przedstawiciele lokalnej ludności oraz hinduscy kupcy ${ }^{49}$. Brak ostrych podziałów etnicznych wynikał z wielu uwarunkowań. Choć za rządów Sa īida doszło do intensywnej rozbudowy miasta, to część dzielnic istniała już wcześniej. Zamieszkiwali je Suahili, a osadnicy z Omanu budowali swoje domy obok ich parcel. Co więcej, nawet w szczytowym momencie migracji Omańczycy stanowili mniejszość mieszkańców miasta ${ }^{50}$. Istotnym czynnikiem był również kosmopolityczny charakter Zanzibaru, żyjącego z handlu i przyciągającego różne grupy etniczne, nawet $\mathrm{z}$ odległych rejonów Oceanu Indyjskiego. Naturalnie występowała tendencja do osiedlania się tych grup we własnych skupiskach, ale

\footnotetext{
${ }^{48}$ Sa'î̀ lbn 'Aī Al-Muḡayrī, Ğuhaynat al-ahbār fi tārīh Zaniğbār ('Pewność wiadomości o historii Zanzibaru'), [red.] 'Muhammad ibn 'Ali Aș-Șalibī, Muscat 2017, s. 78

${ }^{49}$ R.F. Burton, Zanzibar, vol. 1, s. 82

${ }^{50}$ Tamże, s. 368.
} 


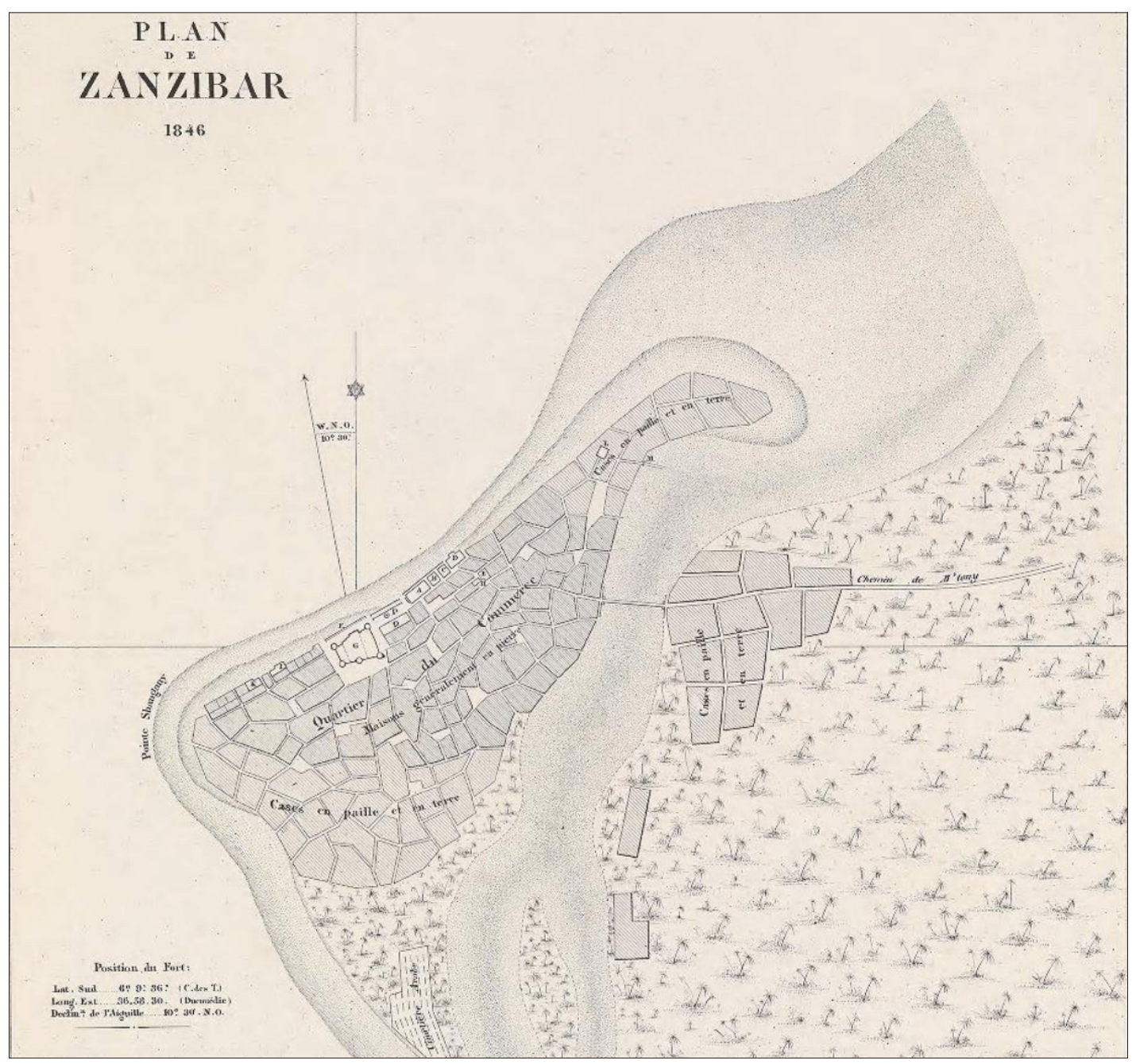

Ryc. 4. Miasto Zanzibar w $1846 \mathrm{r}$.

Źródło: Ch. Guillain, „Voyage à la còte orientale d'Afrique. Exécuté pendant les années 1846, 1847 et 1848 par le brick le Ducouëdic, sous le commandement de M. Guillain. Album", Paris 1856, s. 9

mobilność i zależności handlowe w obrębie miasta sprawiały, że w wielu dystryktach znajdujemy różne grupy etniczne zamieszkujące obok siebie $e^{51}$.

Powielono natomiast omańskie wzorce lokalizacji głównych budynków przy nadbrzeżu. Zarówno fort, jak i pałac władcy (o którym więcej poniżej) znajdowały się tuż przy oceanie. W późniejszym czasie dobudowano przy nadbrzeżu komorę celną

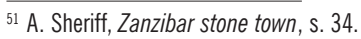

oraz konsulaty zachodnich mocarstw ${ }^{52}$. Podobnie jak omańskie i suahilijskie miasta Zanzibar miał nieregularną siatkę wąskich ulic, przecinających się w przy kilku głównych placach i targach. Cechą charakterystyczną tego układu są bardzo ostre skrzyżowania niektórych arterii oraz częste występowanie ślepych zaułków, co świadczy o chaotycznym i bardzo szybkim

${ }^{52} \mathrm{Ch}$. Guillain, Voyage à la còte orientale d'Afrique. Exécuté pendant les années 1846, 1847 et 1848 par le brick le Ducouëdic. Album, Paris 1856, s. 9. 
rozwoju urbanistyki Zanzibaru, kiedy migranci lub całe rodziny i grupy nabywały kolejne wolne działki, a następnie dzieliły i zabudowywały parcelę po parceli. Proces ten miał charakter spontaniczny, odbywał się bowiem bez nadzoru władzy centralnej, a nie funkcjonowały też władze miejskie, które mogłyby wytyczać i planować rozwój miasta ${ }^{53}$.

Generalną zmianą, która zaszła w omańskim osadnictwie pod wpływem geograficznych i klimatycznych uwarunkowań Afryki Wschodniej, było wprowadzenie koralowca jako głównego materiału budowlanego. Znano go co prawda również w Omanie, lecz wykorzystywany był tam bardzo rzadko, a przykładem są ruiny wzniesionego $\mathrm{w}$ XIV w. mauzoleum Bibi Maryam w Qalhacie. Na Zanzibarze Omańczycy podążali natomiast za tradycją suahilijskich kamiennych rezydencji i miast, budując $z$ tego materiału swoje nowe domostwa. Stosowano tam również połączenie gliny i drewna z mułem, ale stanowiło ono budulec domów niższych warstw społeczeństwa ${ }^{54}$.

Mimo zmiany materiału budowlanego architektura omańskich domów na Zanzibarze była próbą kontynuowania rodzimych tradycji. Zachowano prostą elewację zewnętrzną, urozmaicaną jedynie rzędami okien, a jedynym elementem o charakterze dekoracyjnym były bogato zdobione drzwi wejściowe ${ }^{55}$. Budynek mieszkalny zazwyczaj składał się z kilku pięter i pokryty był płaskim dachem. Koncentrował się wokół kwadratowego dziedzińca, do którego prowadziło wąskie przejście od strony ulicy. Parter zajmowały magazyn, pokoje służby, kuchnie czy sklep, jeśli budynek stał w mieście. Na piętrze znajdowały się pokoje gościnne, gabinet, sypialnia gospodarza czy pokoje kobiet. Okna pomieszczeń

${ }^{53}$ Zanzibar. A plan for the historic stone town, ed. F. Siravo, Geneva 1996, s. 29

${ }^{54}$ Tamże, s. 17.

${ }^{55} \mathrm{Ch}$. New, Life, wanderings and labours in Eastern Africa. With an account of the first successful ascent, London 1874, s. 27. mieszkalnych wychodzily na dziedziniec, rzadziej na ulicęę.

Nowością było bardzo częste łączenie domów ze sklepami i magazynami, w czym naśladowano suahilijską koncepcję domu-faktorii handlowej w odpowiedzi na nową rolę społeczną i ekonomiczną tysięcy omańskich plantatorów i kupców. Ważne zmiany nastąpiły także w wystroju wnętrz. Podłogi pokrywały perskie dywany lub maty, a w charakterystycznych niszach umieszczano książki i drogocenną porcelanę z Chin czy szkło. Ściany ozdabiane były lustrami, obrazami i zegarami sprowadzanymi z Europy, a funkcję dekoracyjną pełniła również broń, zarówno arabska, jak i perska czy turecka. W sypialniach dominowały wysokie, pięknie dekorowane łóżka, które w większości sprowadzano z Indii. Z pozostałych mebli najpopularniejsze były tradycyjne arabskie skrzynie, a w niektórych domach swoje miejsce znalazły europejskie szafy, sofy i stoły. Ważnym elementem wyposażenia były krzesła $^{57}$. Zarówno w Afryce Wschodniej, jak i w Maskacie takie umeblowanie było innowacją wynikająca z intensywnych kontaktów handlowych Sa īida i bogacenia się omańskich elit.

W architekturze religijnej Omańczycy podążali za zwyczajami z ojczyzny ${ }^{58}$. Najwcześniejszym przykładem tego typu budownictwa w Afryce Wschodniej jest meczet Sa ìda w pobliżu jego pałacu w Mtoni prostokątny budynek o grubych murach z pobielonymi ścianami wewnętrznymi i prostym mihrabem w stylu omańskim. Późniejsze budowle, jak meczet w Chake Chake z lat sześćdziesiątych XIX w., miały już bogatsze dekoracje, wyraźnie nawiązujące do suahilijskich wzorców. Nie była to jednak reguła, gdyż pochodzący z tego samego okresu meczet $\mathrm{Al}$ -Mandirīch w Zanzibarze charakteryzował

\footnotetext{
${ }^{56}$ R.F. Burton, Zanzibar, vol. 1, s. 40.

${ }^{57}$ E. Ruete, Memoirs of an Arabian princess. An autobiography, London 1888 , s. 25.

${ }^{58}$ R.F. Burton, Zanzibar, vol. 1, s. 84.
} 
się brakiem dekoracji i prostym mihrabem $^{59}$. Widoczna i trwała zmiana nastapiła natomiast $\mathrm{w}$ wyglądzie cmentarzy. Proste płyty nagrobne zastąpione zostały przez zdobione nagrobki, a sam Sa'ìd i zmarty przed nim syn Haalid mieli spoczywać w budynku przypominającym mauzoleum, co oznaczało porzucenie ibadyckich tradycji pochówku zmarłych ${ }^{60}$.

W innych miastach wybrzeża Afryki Wschodniej zmiany w omańskim osadnictwie wydają się dużo większe. W odróżnieniu od Zanzibaru liczebność omańskiej wspólnoty była tam dużo mniejsza. Na przykład w Mombasie, będącej drugim co do wielkości miastem wybrzeża z populacją szacowaną w omawianym okresie na 15 tys. ${ }^{61}$, Arabów (a więc także Jemeńczyków) było tylko ok. 200-300, a należy od tego odjaćc potomków wcześniejszych imigrantów $^{62}$. Wiemy co prawda, że w Mombasie istniała arabska dzielnica - Gavana, położona po przeciwnej stronie Starego Miasta (Mjiwa Kale) - ale nie mamy żadnych informacji, by istniały tam konkretne podziały plemienne. W innych miejscowościach, jak Kilwa Kivinje, Bagamoyo czy Tanga - istotnych ze względu na handel karawanowy - nie widzimy natomiast żadnych odrębnych arabskich dzielnic, a tym bardziej osobnych dystryktów dla plemion z różnych konfederacji ${ }^{63}$. Można więc przypuszczać, że omańskie osadnictwo było tam bardziej rozproszone i wtopione w lokalną społeczność Suahili, która przez wieki kontaktów handlowych między Arabią i Afryką Wschodnią była dobrze znana Omańczykom. Możliwe też, że część rodzin zamieszkujących takie ośrodki jak Bagamoyo czy Kilwa przebywała tam

\footnotetext{
${ }^{59} \mathrm{M}$. Horton, Ibadis in East Africa, w: Oman and overseas (Studies on Ibadism and Oman), ed. A. Al Salimi, M. Hoffmann-Ruf, Zurich-New York 2013, s. 100-101.

${ }^{60}$ R.F. Burton, Zanzibar, vol. 1, s. 395.

${ }^{61}$ Ch. New, Life, s. 80.

${ }^{62}$ F.J. Berg, Mombasa under the Busaidi sultanate. The city and its hinterlands in the nineteenth century, praca doktorska, Uniwersytet Wisconsin, 1971, s. 152.

${ }^{63}$ Sa'īd Ibn 'Aґ̄ Al-Muḡayrī, Ğuhaynat, s. 144.
}

okresowo, mając swoje stałe rezydencje na Zanzibarze. Ich domy mogły być więc wynajmowane lub kupowane od suahilijskich sąsiadów, a co za tym idzie - wybudowane zgodnie z lokalną tradycją.

\section{Pałace i rezydencje na plantacjach}

Prawdziwa rewolucja nastąpiła w koncepcjach rezydencji władcy i posiadłości wiejskiej. Przeniesienie centrum władzy z Omanu na Zanzibar wiązało się z koniecznością budowy odpowiedniej siedziby dla Sa'īda i rezydencji dla jego urzędników. Pierwszymi domami władcy były pałac w Mtoni i Bayt As-Sahil. Ten ostatni pełnił funkcję głównej rezydencji Sa`īda. Był to dwukondygnacyjny budynek o białych ścianach i regularnym kształcie, $\mathrm{z}$ dachem pokrytym czerwonymi dachówkami i werandą od strony morza. Wydaje się, że jego konstrukcja przypominała rozwiązania zastosowane za czasów ojca Sa īda przy budowie Bayt Al-Ğarayza w Maskacie ${ }^{64}$. Warto jednak zwrócić uwagę, że Bayt Al-Garayza to pierwsza tego typu budowla w Omanie ${ }^{65}$. Architektura Bayt As-Sahil była więc przeniesieniem z Omanu stosunkowo nowych wzorców. Dachówka czy weranda nie były rozwiązaniami omańskimi i praktycznie ich tam nie znano, za to koncepcja prostej fasady zewnętrznej, za którą krył się wewnętrzny dziedziniec, była powszechna.

Drugą ważną rezydencją władcy był położony kilka kilometrów na północ od miasta Zanzibar Bayt Mtoni, którego budowa rozpoczęła się w 1826 r. Pod kilkoma względami jest to założenie niezwykle istotne. Wydaje się, że było pierwszą posiadłością władców Omanu mającą charakter głównie rekreacyjny. Badania archeologiczne wskazały co prawda na istnienie okrągłej wieży przypominającej

\footnotetext{
${ }^{64}$ D. Rhodes, C. Breen, W. Forsythe, Zanzibar. A nineteenth-century landscape of the Omani elite, w: „International Journal of Historical Archaeology", 19, 2015, s. 344.

${ }^{65}$ P. Risso, Oman and Muscat. An early modern history, London 1986, s. 114.
} 


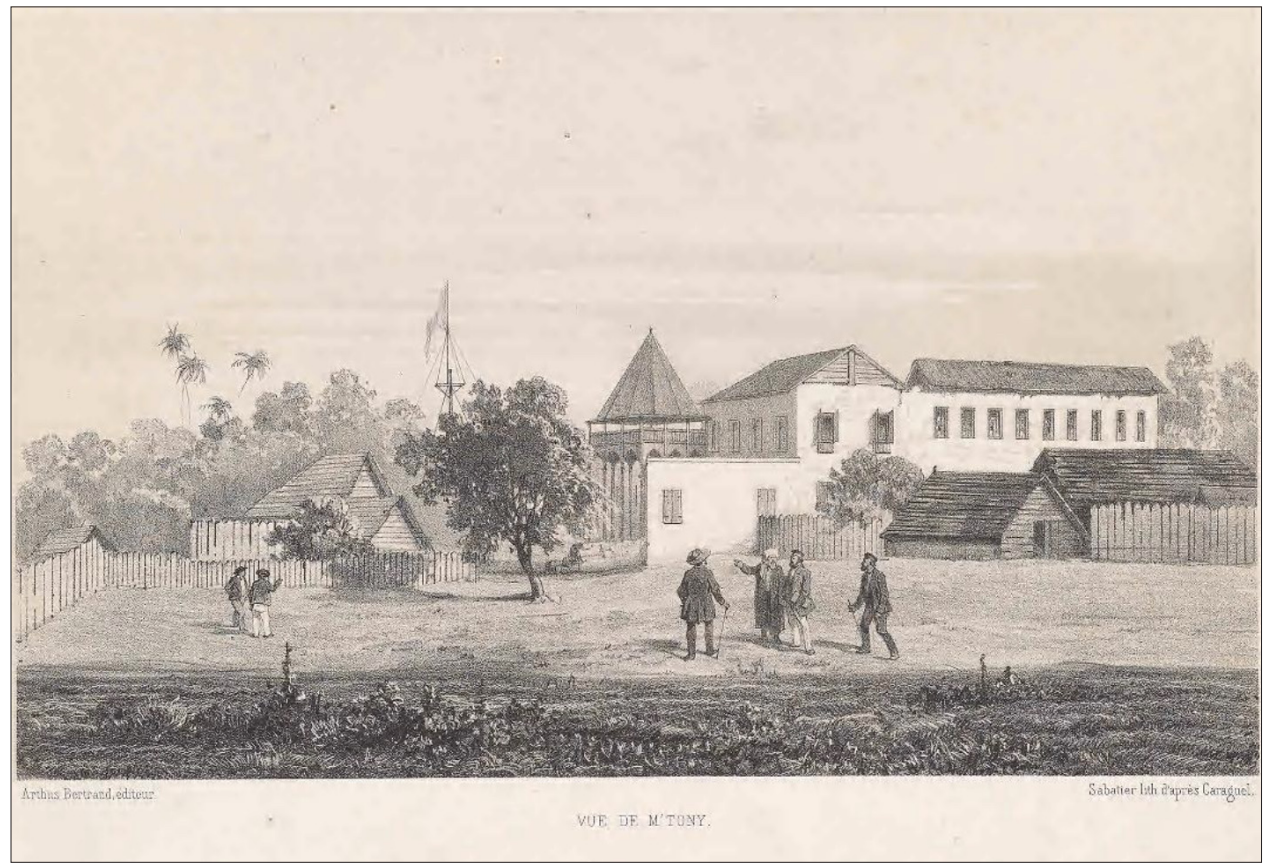

Ryc. 5. Pałac w Mtoni.

Żródto: Ch. Guillain, „Voyage”, Paris 1856, s. 5

konstrukcje z omańskich fortów, jednak szczegóły dotyczące jej funkcji i wyglądu nie są znane ${ }^{66}$. Istnienie wieży obronnej nie przekreśla podstawowej roli tego kompleksu, a więc miejsca do rekreacji. Świadczy o tym rozległy ogród z drzewami pomarańczy i kokosa oraz altana - benjile. Był to duży okrągły drewniany budynek z malowanymi drewnianymi balustradami i dachem przypominającym zwieńczenie namiotu. Znajdował się nad brzegiem morza, służąc Sa îdowi za miejsce odpoczynku ${ }^{67}$.

Układ kompleksu odzwierciedlał omańskie tradycje architektoniczne z zamkniętym dziedzińcem i usytuowanym wewnątrz kanałem, co przypominało budowę twierdz w Omanie mających dostęp do falağy. Omańskim rozwiązaniem, które przeniesiono do Mtoni, była również specjalna sala audiencyjna - baraza. Znajdowała się na parterze pałacu, a widok z jej okien

\footnotetext{
${ }^{66}$ D. Rhodes, C. Breen, W. Forsythe, Zanzibar, s. 345.

${ }^{67}$ E. Ruete, Memoirs, s. 12
}

wychodził na wody oceanu ${ }^{68}$. W Omanie rozwiązanie takie można zaobserwować na przykład w siedemnastowiecznej fortecy w Nahll. Znajdująca się tam baraza jest wysoką podłużną prostokątną salą na trzecim piętrze, z której widać otaczające fort oazy. Nowością w omańskiej architekturze Mtoni jest ulokowanie wejścia do pałacu od strony morza oraz utworzenie kompleksu łaźni. Dodatkowo budynek miał się wyróżniać kopułą oraz pięknym stylem wykończenia ${ }^{69}$. Zastosowanie konstrukcji kopuły to ciekawa innowacja, bo choć jest ona jedną z charakterystycznych cech architektury arabskiej, to w Omanie spotykano ją rzadko, a zdecydowana większość dachów była płaska. Wydaje się zatem, że mamy tutaj do czynienia z wyraźnym zapożyczeniem z tradycji Suahili.

Koncepcje zastosowane w Mtoni stały się inspiracją dla powstania omańskich

\footnotetext{
${ }^{68}$ Tamże, s. 139.

${ }^{69}$ J.B.F. Osgood, Notes of travel; or, Recollections of Majunga, Zanzibar, Muscat, Aden, Mocha, and other eastern ports, Salem 1854, s. 64.
} 
rezydencji na plantacjach goździków, które same w sobie również były innowacją. Dotychczas w Afryce Wschodniej istniały co prawda plantacje kokosów, ale goździki zaczęły być uprawiane dopiero na początku XIX w. Choć nie jest to pewne, przyjmuje się, że za wprowadzeniem tej uprawy na Zanzibar stał sam władca, dzielący się nasionami drzewa goździkowego z przybywającymi z Omanu Arabami ${ }^{70}$. Plantacje rozwijały się zarówno na Zanzibarze, jak i na Pembie. Na drugiej z tych wysp nastąpiło to jednak z pewnym opóźnieniem, a szczyt rozwoju upraw odnotowuje się tam dopiero po 1872 r., kiedy większość zanzibarskich uległa zniszczeniu w wyniku huraganu. Plantacja goździków wymagała ciemnej gliniastej ziemi i takie tereny znajdowały się w północno-zachodniej części wyspy Zanzibar oraz na większości obszaru Pemby $^{71}$. Zasięg odpowiedniej gleby był pierwszym elementem, który ograniczał powstawanie kompleksów plantacji, a co za tym idzie - omańskie osadnictwo.

Charakterystyczną cechą tego typu osadnictwa było spore rozproszenie, inaczej bowiem niż w Omanie plantacje goździków nie otaczały tutaj osad czy miast, ale funkcjonowały jako niezależne kompleksy o różnej wielkości. Mogły być zlokalizowane w pobliżu osad lub miejscowości albo na terenach dziewiczych. W początkowym okresie zakładano je w sporej odległości od innych zabudowań i dopiero w późniejszym czasie, gdy areał odpowiedniej ziemi został pokryty plantacjami, ich gęstość wzrosła ${ }^{72}$.

${ }^{70} \mathrm{~F}$. Cooper, Plantation slavery on the east coast of Africa, Portsmouth 1997, s. 58.

${ }^{71}$ W.W.A. Fitzgerald, Travels in the coastlands of British East Africa and the islands of Zanzibar and Pemba. Their agricultural resources and general characteristics, London 1898, s. 530.

${ }^{72}$ Wydaje się, że większość plantacji nabywano, zajmując nieużytki, co zgodnie z prawem muzułmańskim dawało tytuł prawny do ziemi. Innymi sposobami były zakup ziemi lub małżeństwa z przedstawicielkami lokalnej ludności. Nie zawsze jednak tworzenie plantacji następowało pokojowo; zdarzało się zbrojne zabieranie ziemi należącej do lokalnej ludności lub przejmowanie terenów pogranicznych. Więcej zob.: J. Middleton, Land tenure in Zanzibar and Pemba, London 1961, s. 12; C.S. Nicholls, The Swahili coast, s. 30.
Poza ziemiami przeznaczonymi pod uprawę typowa plantacja składała się z rezydencji właściciela oraz rzędu chat, w których mieszkali pracujący na niej niewolnicy. Przy większych plantacjach powstały całe wioski z meczetem i $\operatorname{targiem}^{73}$. Początkowo prawie wszystkie posiadłości znajdowały się w rękach Omańczyków, a ich wielkość zależała od zamożności i przedsiębiorczości właściciela. Większy kompleks plantacji mógł liczyć ponad 10 tys. drzew i być miejscem pracy dla 2 tys. niewolników ${ }^{74}$.

Powstanie upraw goździków wytworzyło nowy typ osadnictwa - rezydencje na plantacjach $^{75}$. Warto jednak podkreślić, że w pierwszych latach rozwoju tej gałęzi rolnictwa bardzo niewielu Omańczyków rezydowało na stałe $\mathrm{w}$ posiadłości ziemskiej. Większość zamieszkiwała w Zanzibarze, a pracami kierowali nadzorcy lub doświadczeni niewolnicy. Z czasem jednak, podążając śladami Sa īda, Omańczycy zaczęli spędzać na plantacjach więcej czasu, szczególnie w okresie zbiorów, stąd też wynikła konieczność budowy odpowiednich rezydencji ${ }^{76}$. Najbogatsi plantatorzy starali się naśladować kamienne domy z Zanzibaru i innych miast wybrzeża, dlatego wznosili swoje budynki z koralowca i wykańczali gipsem, nadając im prostokątny kształt. W odróżnieniu od domów w mieście nie miały one wielu poziomów i zazwyczaj ograniczały się do parteru i pierwszego piętra. Nie funkcjonował również zamknięty dziedziniec, ale istniało pomieszczenie barazy, z której widać było plantację, a w szczególności miejsce suszenia goździków ${ }^{77}$.

\footnotetext{
${ }^{73} \mathrm{~J}$. Middleton, Land tenure, s. 42.

${ }^{74}$ F. Cooper, Plantation, s. 68.

${ }^{75}$ Więcej 0 plantacjach jako fenomenie społecznym i kulturowym oraz o osadnictwie niewolników: S. Żbik, Arabskie plantacje goździków na Zanzibarze i Pembie w XIX w.: uwarunkowania spoteczne i kulturowe, „Afryka”, 45, 2017, s. 99-134.

${ }^{76}$ F. Cooper, Plantation, s. 73.

${ }^{77}$ S. Croucher, Cloves and capitalism. An archaeology of plantation life on nineteenth-century Zanzibar, New York 2015, s. 150.
} 
Na podstawie źródeł trudno uchwycić szczegółowy rozkład i wygląd wnętrz rezydencji. Opisy przekazane przez europejskich podróżników lub brytyjskich urzędników nie zawierają zbyt wielu informacji na temat budowli. Pozostałości archeologiczne dotyczą zaś głównie późniejszego okresu, a te, które zostały zachowane, prezentują stan uniemożliwiający dogłębną analizę wewnętrznego układu rezydencji ${ }^{78}$. Niemniej jednak na podstawie dotychczasowych badań archeologicznych możemy potwierdzić występowanie charakterystycznych zdobionych drzwi, które znajdowały się w głównym wejściu do budynku ${ }^{79}$.

Choć w zakresie rozwiązań konstrukcyjnych i architektonicznych rezydencje na plantacjach i pałac w Mtoni czerpały z omańskich tradycji, to jednak były przejawami nowego typu omańskiego osadnictwa, niosącego za sobą nową jakość społeczną i kulturową. Mamy tu do czynienia z budowlami, które łączyły funkcje ekonomiczne i administracyjne z wymiarem rekreacyjnym. Wznoszono je w sporym rozproszeniu, w związku z czym funkcjonowały jako autonomiczne kompleksy niebędące częścią osad ani miast. Uzależnienie uprawy od jakości gleby i regularnych deszczy wymuszało zerwanie z kolektywnym charakterem rolnictwa, które w Omanie zależne było od wody ze studni i kanałów, czerpanej $\mathrm{w}$ porozumieniu z lokalną wspólnotą i w ściśle regulowany sposób. Rezydencje na plantacjach zapewniały Omańczykom rekreację, ale także pewną separację, co również było sporą nowością dla tego plemiennego społeczeństwa. Nie oznaczało to jednak przerwania kontaktów społecznych. $\mathrm{Z}$ materiałów źródłowych wynika bowiem, że omańscy plantatorzy byli dość mobilni - odwiedzali rodzinę i przyjaciół na sąsiednich plantacjach, a zarządzanie nimi wymuszało też częste wizyty w mieście ${ }^{80}$.

\footnotetext{
${ }^{78}$ Tamże, s. 151.

${ }^{79}$ Tamże.

${ }^{80}$ E. Ruete, Memoirs, s. 194.
}

\section{Omańskie osadnictwo w interiorze}

Ciekawym przykładem omańskiego osadnictwa w Afryce Wschodniej są osady w interiorze kontynentu, powstające wraz z rozwojem handlu karawanowego. Najważniejszą była Tabora, położona ok. $880 \mathrm{~km}$ od wybrzeża, co czyniło ją jednym z najdalej wysuniętych na zachód punktów Afryki zamieszkiwanych przez Omańczyków. Tabora leżała w regionie Unyanyembe, który z kolei stanowił część obszaru Unyamwezi. Tereny te zamieszkiwane były przez ludy Nyamwezi, składające się z kilku grup etnicznych pochodzenia Bantu, podzielonych na liczne wodzostwa ${ }^{81}$.

Rola Unyanyembe wzrastała, gdy popyt na niewolników i kość słoniową zaczął przewyższać podaż na dotychczasowych szlakach i omańscy oraz suahilijscy kupcy postanowili rozwinąć istniejący już szlak karawanowy w kierunku jeziora Tanganika. Pierwszymi osobami z Zanzibaru, które dotarły na ziemie Nyamwezi, byli zapewne hinduscy kupcy, wysłani tam z polecenia namiestnika Sa īda jeszcze ok. 1824 r. W latach czterdziestych region Nyamwezi był już regularnie odwiedzany przez arabskich kupców, a w 1852 r. istniała tam stała omańska osada. Wybór Unyanyembe na miejsce omańskiego osadnictwa w interiorze podyktowany był kilkoma czynnikami. Przede wszystkim region był centralą handlu karawanowego, pozwalającą na uruchomienie komunikacji na trasie między jeziorem Tanganika i wybrzeżem na wschodzie. Drugą istotną kwestią był dostęp do dobrej gleby, pozwalającej na uprawę roli ${ }^{82}$.

Dokładna wielkość omańskiej diaspory w Taborze za czasów Sa īda nie jest znana ${ }^{83}$. Richard Burton szacuje, że pod koniec lat pięćdziesiątych XIX w. w sezonie handlowym mieszkało tam ok. 25 kupców, a gdy się kończył, ich liczba spadała do zaledwie

\footnotetext{
${ }^{81}$ J.C. Wilkinson, The Arabs and the scramble for Africa, Bristol 2015, S. 85.

${ }^{82}$ R.F. Burton, The lake regions of Central Africa. A picture of exploration, vol. 1, London 1860 , s. 228

${ }^{83}$ J.C. Wilkinson, The Arabs, s. 91.
} 


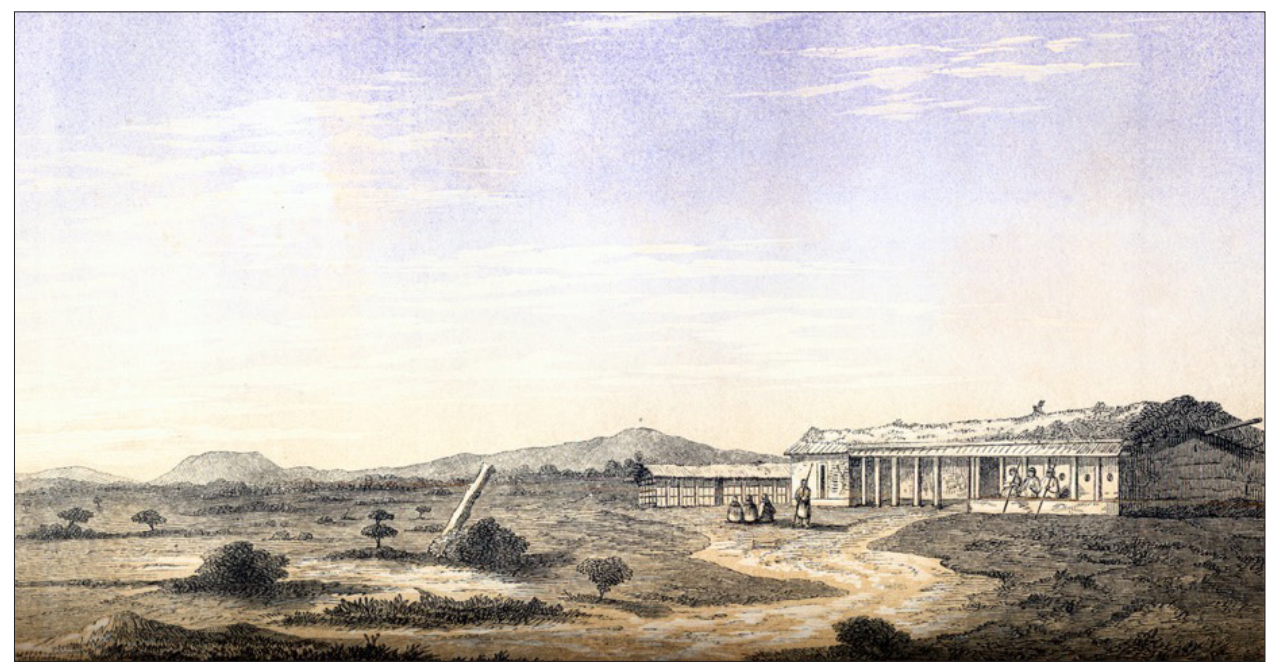

Ryc. 6. Tembe Snaya Ibn Amra.

Źródto: R.F. Burton, "The lake regions"

kilku ${ }^{84}$. Faktem jest, że omańskie osadnictwo na tych terenach miało charakter tymczasowy, uzależniony od reguł handlu karawanowego, a jednak tamtejsi Arabowie mieli żyć komfortowo, w rozległych posiadłościach z ogrodami i plantacjami. W domostwach kupców mieszkała też służba, strażnicy i pozostali niewolnicy, a także konkubiny, dla których budowano osobne haremy ${ }^{85}$.

Domy wznoszone w interiorze były dużymi jednopoziomowymi budynkami pozwalającymi na odparcie ewentualnego ataku. Ich konstrukcja przypominała tembe - tradycyjne domostwo afrykańskie ${ }^{86}$, ale wprowadzono kilka ważnych modyfikacji. Przede wszystkim miały odpowiednio zacienioną zewnętrzną werandę, gdzie podejmowano gości i spędzano czas w pracy i poza nią. Masywne drzwi broniły wejścia do wnętrza domu, gdzie znajdowała się tradycyjna duża sala gościnna - baraza, o wiele skromniejsza jednak niż na Zanzibarze czy w Omanie. Podstawowym

${ }^{84}$ R.F. Burton, The lake regions, s. 229.

${ }^{85}$ Tamże, s. 230.

${ }^{86}$ Był to podłużny prostokątny budynek wykonany z drewna, trzciny i liści. Najczęściej kryto go jedno- lub dwuspadowym dachem wykonanym z trzciny i miał tylko jeden poziom. wyposażeniem barazy we wnętrzu kontynentu były glinianie lawy ustawione rzędami po obu stronach ściany oraz maty i dywany na podłodze. Za pokojem gościnnym znajdowała się część domu niedostępna dla obcych. Pokoje gospodarza i harem nie miały okien, a jedyne drzwi wychodziły na podłużny dziedziniec, wokół którego były zlokalizowane. W głębi domu, za pokojami znajdowały się magazyny i budynki gospodarcze $^{87}$. Taki układ uzasadniony był względami bezpieczeństwa oraz charakterem samego domostwa, które pełniło również funkcję faktorii handlowej.

Poza Taborą i przyległymi osadami pojedynczy Omańczycy osiedlali się w innych regionach istotnych dla handlu karawanowego. Należały do nich Ujiji (pięć dni drogi od Unyanyembe), Kasenge (po drugiej stronie jeziora Tanganika) oraz Nyangwe, gdzie akcja osadnicza nastąpiła już po 1856 r. ${ }^{88}$ Omańczycy osiedlali się w tych miejscach jedynie tymczasowo, w związku z dalszymi ekspedycjami w głąb kontynentu, dlatego korzystali głównie z zastanych form i stylów osadniczych - przede

\footnotetext{
${ }^{87}$ R.F. Burton, The lake regions, s. 230.

${ }^{88}$ Tenże, Zanzibar, vol. 2, s. 300.
} 
wszystkim konstrukcji tembe. Często mogło się też zdarzać, że omańscy kupcy podróżujący przez te tereny zatrzymywali się w domach lokalnych wodzów lub rozbijali namioty jedynie na czas postoju.

\section{Podsumowanie}

W omańskim modelu osadnictwa, który w latach 1806-1856 zastosowany został w Afryce Wschodniej, można dostrzec dwie równoległe tendencje. $Z$ jednej strony nastąpiły istotne zmiany wynikające z warunków geograficznych i społecznych tych ziem. Do najważniejszych należało przejście z suszonej cegły na koralowiec, wprowadzenie kopuły, porzucenie ścisłego podziału na osobne dla Omańczyków i innych grup etnicznych dzielnice czy przejęcie w interiorze konstrukcji tembe - jako nowego omańskiego domu. Inne wynikały z przemian gospodarczych i społecznych, jakie wywołała polityka Sa īda Ibn Sultāna. Wprowadzenie plantacji goździków skutkowało pojawieniem się nowego typu rezydencji, a rozkwit handlu karawanowego - adaptacją tembe. Dochody i awans społeczny, jakie oferowała Arabom z Omanu Afryka Wschodnia, przyczynity się do powstania idei posiadłości rekreacyjnej oraz ograniczenia obronnego charakteru omańskiego osadnictwa. Rozszerzenie obecności Omańczyków aż do interioru Afryki Wschodniej oraz rozproszony i autonomiczny charakter plantacji goździków sprzyjały ograniczeniu kolektywnego oblicza społeczeństwa. Więzy rodowe i społeczne nadal były istotne, ale siła szejka czy lokalnej wspólnoty została osłabiona. Uniezależnieniu się jednostki od wyższych struktur społecznych sprzyjały spora mobilność i możliwości szybkiego wzbogacenia się.

Bardzo wiele elementów osadnictwa zostało też jednak przeniesionych z Omanu. Wciąż realizowano je w oparciu o strukturę trybalistyczną i sojusze plemienne, a architektura i wystrój domów, pałaców oraz meczetów nawiązywały do rodzimych tradycji. Nawet w dalekim interiorze wprowadzono takie pomieszczenia jak znana z omańskich domów i zamków baraza. Zgodnie z tradycjami pustynnego Omanu wznoszono też nowe rezydencje na plantacjach i w Mtoni.

Charakter omańskiego osadnictwa wynikał z faktu, że w czasach przednowoczesnych to właśnie dom - obok języka i religii czy stroju (męskiego) - stanowił wyznacznik tożsamości. Omańczycy byli w Afryce Wschodniej ekonomiczną i polityczną elitą, dlatego musieli podkreślać swoje pochodzenie i dystansować się od liczniejszej wspólnoty Suahili. Co więcej, omańskie osadnictwo w Afryce Wschodniej realizowane było nie tylko w ramach jednego omańskiego państwa, ale także w pobliżu jego centrum, którym od $1840 \mathrm{r}$. był Zanzibar. Z drugiej strony, żyjąc w nowych warunkach gospodarczych i geograficznych czy osiedlając się jedynie tymczasowo (jak w interiorze), Omańczycy musieli dostosowywać się do otaczających ich realiów.

Zarysowana powyżej tendencja trwała również po 1856 r., jednakże po utworzeniu odrębnych sułtanatów Omanu i Zanzibaru w omańskim osadnictwie w Afryce Wschodniej pojawiało się coraz więcej nowych rozwiązań. Najlepszym przykładem jest wybudowany w 1883 r. przez sułtana Barḡaša (1870-1888) pałac Bayt Al-'Ağāỉb (Dom Cudów), który zdecydowanie różnił się od wcześniejszych rozwiązań architektonicznych, zawierając bardzo wiele elementów europejskich i hinduskich. Mimo tych zmian aż do końca Sułtanatu Zanzibaru elementy arabskie ${ }^{89}$ pozostawały istotnym składnikiem krajobrazu Afryki Wschodniej.

\footnotetext{
${ }^{89}$ Warto też podkreślić, że omańskie osadnictwo w Afryce Wschodniej nie było jedynym takim zjawiskiem z kręgu kultury arabskiej. Znaczny udział w migracji na te tereny mieli też Arabowie z innych regionów Półwyspu Arabskiego, szczególnie z Jemenu. W przeciwieństwie jednak do omańskiej społeczności Jemeńczycy nie rozciagali w Afryce władzy politycznej ani nie tworzyli własnych państw na terenach swojego osadnictwa. Więcej na temat jemeńskiej migracji i osadnictwa zob.: U. Freitag, Indian Ocean migrants and state formation in Hadhramaut. Reforming the homeland, Leiden 2003; N. Um, The merchant houses of Mocha. Trade and architecture in an Indian Ocean port, Seattle 2009.
} 


\section{Bibliografia}

Źródła

Albrand F., Extrait d'un memoire sur Zanzibar et sur Quiloa, „Bulletin de la Société de Géographie”, 10, 1838.

Burton R.F., The lake regions of Central Africa. A picture of exploration, vol. 1, London 1860.

Burton R.F., Zanzibar: city, island, and coast, vol. 1-2, London 1872.

Fitzgerald W.W.A., Travels in the coastlands of British East Africa and the islands of Zanzibar and Pemba. Their agricultural resources and general characteristics, London 1898.

Guillain Ch., Voyage à la còte orientale d'Afrique. Exécuté pendant les années 1846, 1847 et 1848 par le brick le Ducouëdic. Album, Paris 1856.

Miles S.B., The countries and tribes of the Persian Gulf, vol. 2, London 1919.

\section{Opracowania}

Allen C.H., The Indian merchant community in Masqat, „Bulletin of SOAS”, 44 (1), 1981.

Berg F.J., Mombasa under the Busaidi sultanate. The city and its hinterlands in the nineteenth century, praca doktorska, Uniwersytet Wisconsin, 1971.

Bhacker M.R., Trade and empire in Muscat and Zanzibar. The roots of British domination, London 2014.

Cooper F., Plantation slavery on the east coast of Africa, Portsmouth 1997.

Costa P.M., Historic mosques and shrines of Oman, London 2001.

Croucher S., Cloves and capitalism. An archaeology of plantation life on nineteenth-century Zanzibar, New York 2015.

Documentation and heritage management plan of Hārat al-Yemen, Muscat 2013.

Donley J., House power. Swahili space and symbolic markers, w: Symbolic and structural archeology, ed. I. Hodder, Cambridge 1982.

Freitag U., Indian Ocean migrants and state formation in Hadhramaut. Reforming the homeland, Leiden 2003.

Ghafiri, Al- A., Nash H., Sarmi, Al- M., Timing water shares in Wādì Bañ̄ Kharūs, Sultanate of Oman, w: Proceedings of the Seminar for Arabian Studies, vol. 43, ed. L. Weeks, J. Watson, London 2013.

Hoffman V.J., The essentials of Ibadi Islam, Syracuse 2012.

Horton M., Ibadis in East Africa, w: Oman and overseas (Studies on Ibadism and Oman), ed. A. Al Salimi, M. Hoffmann-Ruf, Zurich-New York 2013.
Muḡayrī, Al-Sa īd Ibn 'Alī, Ğuhaynat al-ahbār fì tārīh Zaniğbār ('Pewność wiadomości o historii Zanzibaru'), [red.] 'Muhammad Ibn 'Alī Aș-Ṣalībī, Muscat 2017.

Osgood J.B.F., Notes of travel; or, Recollections of Majunga, Zanzibar, Muscat, Aden, Mocha, and other eastern ports, Salem 1854.

Roberts E., Embassy to the eastern courts of Cochin-China, Siam, and Muscat, New York 1837.

Ruete E., Memoirs of an Arabian princess. An autobiography, London 1888.

Ruschenberger W.S., Narrative of a voyage round the world, vol. 1-2, London 1838.

Ibrahim M.M., Tombs and their inscriptions from Nizwa and al-Haymalī, Sultanate of Oman, w: Proceedings of the Seminar for Arabian Studies, vol. 31, Oxford 2001.

Ibri, Harat As-Sulayf. Documentation and heritage management plan, Muscat 2013.

Joelson F.S., The Tanganyika territory (formerly German East Africa). Characteristics and potentialities, London 1920.

Jones J., Ridout N., A history of modern Oman, London 2015.

Kajari F., Le Sultanat d'Oman. La question de Mascate, Paris 1914.

Maurizi V., History of Seyd Said, Sultan of Muscat, London 1819.

Middleton J., Land tenure in Zanzibar and Pemba, London 1961.

New Ch., Life, wanderings and labours in Eastern Africa. With an account of the first successful ascent, London 1874.

Nicholls C.S., The Swahili coast. Politics, diplomacy and trade on the East African littoral, 1798-1856, London 1971.

Nicolini B., Makran, Oman and Zanzibar. Three-terminal cultural corridor in the western Indian Ocean (1799-1856), Leiden 2004.

Oman and overseas (Studies on Ibadism and Oman), ed. A. Al Salimi, M. Hoffmann-Ruf, Zurich-New York 2013.

Pearson M.N., Port cities and intruders. The Swabili Coast, India and Portugal in the early modern era, Baltimore 1998. 
Pouwels R.L., Horn and crescent. Cultural change and traditional Islam on the East African coast, Cambridge 2002 .

Rhodes D., Breen C., Forsythe W., Zanzibar. A nineteenth-century landscape of the Omani elite, „International Journal of Historical Archaeology”, 19, 2015.

Risso P., Oman and Muscat. An early modern history, London 1986.

Sheriff A., Zanzibar stone town. An architectural exploration, Zanzibar 1998.

Um N., The merchant houses of Mocha. Trade and architecture in an Indian Ocean port, Seattle 2009.
Wilkinson J.C., The Arabs and the scramble for Africa, Bristol 2015.

Wilkinson J.C., The imamate tradition of Oman, Cambridge 1997.

Wilkinson J.C., Water and tribal settlement in Southeast Arabia. Study of the aflaj of Oman, Oxford 1997.

Zanzibar. A plan for the historic stone town, ed. F. Siravo, Geneva 1996.

Żbik S., Arabskie plantacje goździków na Zanzibarze i Pembie w XIX w.: uwarunkowania spoteczne i kulturowe, „Afryka”, 45, 2017.

\section{The Impact of the Geographical, Social and Economic Environment of East Africa on the Oman Settlement Model in 1806-1856}

\section{Summary}

In 1806-1856, thousands of Omani settled in East Africa. They left a desert country characterized by a hot climate, where the settlement model was determined by the limited access to water and the tribal character of society. In East Africa, they lived as a minority among non-Arab communities, and their new homes had to withstand heavy rains and a tropical climate. In Oman they lived mainly from the cultivation of date palm and breeding, while in the new environment they became clove growers and merchants involved in caravan trade. The present article analyses the impact of these different geographical, social and economic conditions on the settlement model of the Omani in East Africa. The subject of this analysis is Oman settlement in cities, on plantations, and in the interior of East Africa. The article indicates that the Omani settlement model has undergone significant changes, including the appearance of new forms of settlement, a change in building material, and the adoption of solutions practiced by African cultures. On the other hand, however, many important elements, such as architecture and tribal settlement structure, were transferred to East Africa.

Sebastian Żbik - arabista i historyk, doktorant w Instytucie Historycznym UW. Zajmuje się historią Bliskiego Wschodu w XIX i XX w., ze szczególnym uwzględnieniem Omanu i jego kontaktów z Afryką Wschodnią (sebastian.zbik@uw.edu.pl)

Sebastian Żbik - Arabist and historian, PhD student at the Institute of History of the University of Warsaw. He deals with the history of the Middle East in the $19^{\text {th }}$ and $20^{\text {th }}$ centuries, with particular emphasis on Oman and its contacts with East Africa

(sebastian.zbik@uw.edu.pl) 